\title{
Immunopathological modifications in the rectal mucosa from an animal model of food allergy
}

\author{
M. Vinuesa, N. Bassan, S. Roma and F. Pérez \\ Department of Histology and Embriology. School of Medicine. Universidad Nacional de Rosario. Rosario, Santa Fe. \\ Argentina
}

\begin{abstract}
Aim: the aim is to determine immunopathological modifications in rectal mucosa from rabbit after local challenge in sensitized animals with ovalbumin (OVA).

Experimental design: thirty rabbits divided into three groups: G1: normal, G2: subcutaneously OVA sensitized, G3: sensitized, locally OVA challenged and sampled 4 hours after challenge. Specific anti-OVA IgE levels were evaluated by passive cutaneous anaphylaxis test (PCA). In each group 200 high microscopical power fields (HPF) were counted. Results were expressed as arithmetic mean and SE. Statistical analysis was made using Student $\mathrm{t}$ test. Anti-CD4, CD5, $\mu$ chain, CD25 and RLA II monoclonal antibodies were used. Avidin biotin horseradish peroxidase system was used.

Results: CD 4: G1: $8,3 \pm 0,06 ; G 2: 13,4 \pm 0,08$ and G3: 8,25 $\pm 0,06$. CD 5: G1: 7,3 $\pm 0,05 ; G 2: 9,4 \pm 0,05$ and G3: $11,3 \pm 0,06 . \mathrm{CD} 25: \mathrm{G} 1: 13 \pm 0,08 ; \mathrm{G} 2: 15,1 \pm 0,13$ and G3: $25,5 \pm 0,15$. $\mu$ chain: G1: $10,4 \pm 0,06 ; G 2: 3,8 \pm 0,02$ and G3: $6,0 \pm 0,10$. RLA II (DR): G1: $11,6 \pm 0,05 ;$ G2: $19,2 \pm 0,09$ and G3: $19,1 \pm 0,11$. In all cases, experimental groups (G2 and G3) presented statistical significant differences vs. control group (G1) $(\mathrm{p}<0.001)$.

Conclusions: interleukin- 2 receptor (CD25+ cells) increase in experimental groups. Cells expressing $\mu$ chain decreased in G2 and G3 likely due to activation of B cells and subsequent expression of other immunoglobulin chains in cell surface. RLA II expression is higher in G2 and G3. This receptor is considered an activation marker expressed by macrophages, $\mathrm{T}$ and $\mathrm{B}$ cells. We conclude that obtained data are important to elucidate immunopathology of local anaphylactic reaction in rectal mucosa from systemic sensitized animals.
\end{abstract}

Key word: Immunopathology. Rectal mucosa. Rabbits. Food allergy.

Recibido: 08-10-03.

Aceptado: 12-04-05.

Correspondencia: Miguel Ángel Vinuesa. Superí, 247. 2000 Rosario, Santa Fe. República Argentina. e-mail: mvinuesa@uolsinectis.com.ar - miguelvinuesa@uolsinectis.com.ar
Vinuesa M, Bassan N, Roma S, Pérez F. Immunopathological modifications in the rectal mucosa from an animal model of food allergy. Rev Esp Enferm Dig 2005; 97: 629-636.

\section{INTRODUCTION}

Food allergy is considered an abnormal immune response in previously sensitized individuals after the oral ingestion of an offending food allergen $(1,2)$.

Food allegens may be incorporated in the digestive tract through an appropriate penetration of molecules, which induces tolerance (3), or an abnormal penetration (altered mucosal barrier), which induces sensitization and high IgE production, which in turn binds mast cells and basophils (4-8).

A newly ingested allergen in a sensitized individual develops an acute anaphylactic inflammatory reaction (9-11). This response induces qualitative and quantitative modifications in immune cells at the mucosa.

It is estimated that $0.2 \%$ of the population has food allergy symptoms. In the USA, 5\% of children under 3 years and $1.5 \%$ of the general population (about 4,000,000 people) show food allergy symptoms (12).

Allergens may be normal compounds of nutrients, additives or some transgenic variety of food protein. Besides, the way of cooking may increase or decrease the antigenic properties of food allergens. Modifications of molecular characteristic could induce cross reactions (13).

Most common food allergens are cow milk, eggs, whey, tomato, chocolate, peanut, kiwi, fish, oyster, shellfish (14).

Cross allergy reactions with fruits (banana and kiwi) may be observed in latex (Hebea brasiliensis) sensitized people $(15,16)$. The rectum may also be considered the organ for antigen penetration in case of gloves for rectal examination, rectal probes, and condoms in anal coitus. Rab- 
bits are a useful model for food allergy experimentation (17). Lagomorphs have an important genetic preservation in humans, and generate high levels of IgE after subcutaneous sensitization. Besides, high amounts of potentially antigenic food macromolecules reach distal regions of the colon due to the physiologic process of cecotrophy (18$20)$. The rectum is a part of the common immune mucosal system (CMIS), so histopathological and immunological modifications due to sensitization and challenge may be evaluated in the rectal mucosa (21-24).

The aim of the present work is to find quantitative modifications in the immune-cell population of the rectal mucosa as established in an animal model of food allergy.

\section{MATERIALS AND METHODS}

Thirty adult New Zealand rabbits were divided into 3 groups: group 1: $(\mathrm{n}=10)$ normal controls; group 2: $(\mathrm{n}=10)$ ovalbumin (OVA) sensitization subcutaneously (SC); group 3: $(n=10)$ OVA-sensitized subcutaneously (SC) and OVA-challenged rectally.

The rabbits in groups 2 and 3 were subcutaneously sensitized on two occasions with $70 \mu \mathrm{g}$ OVA in $30 \mathrm{mg}$ ALUM/ml (aluminium hydroxide). An interval of 15 days among sensitizations was established.

After 15 days post-sensitization, the rabbits were fasted for 24 hours and G3 animals were rectally challenged with $50 \mathrm{mg}$ OVA in $5 \mathrm{ml}$ of PBS (21).

Animals were sacrificed with sulfuric ether 4 hours after being challenged, according to considerations by the Ethical Committee of Rosario School of Medicine. Samples from the rectum were obtained for all groups.

Materials for immunohistochemistry were snap-frozen in liquid nitrogen with an OCT protector and then stored at $-20{ }^{\circ} \mathrm{C}$ and cut in 8-micrometer slices. Samples for histology were paraffin-embedded and then cut in 6-micrometer slices.

The following monoclonal antibodies were used:

- Mouse anti-rabbit CD5 (KEN-5, BALB/c IgG 1, Biosource, Camarillo, California, USA), for mature total T-cell and B-cell subset identification.

-Mouse anti-rabbit CD4 (KEN-4, BALB/c IgG 2a, Biosource, Camarillo, California, USA) for CD4+ T-cell identification (25).

-Mouse anti-rabbit CD25 (KEI-alfa 1, BALB/c IgG 2b, Pharmingen, San Diego, California, USA), IL-2 receptor, also considered a cell activation marker (25).

-Mouse anti-rabbit immunoglobulin $\mathrm{M}$ ( $\mu$ chain, NRBM BALB/c IgG 1, Biosource, Camarillo, California, USA), a B-cell marker.

- Mouse anti-rabbit RLA-DR (RDR34, BALB/c IgG 2b, Pharmingen, San Diego, California, USA) for RLA DR (similar to human HLA DR), an activation marker in antigen-presenting cells.

A biotin-streptavidin system (Serotec Ltd. Oxford, UK) was used for the detection of marked cells and AEC as chromogen.
Frozen samples were fixed in cold acetone for $10 \mathrm{~min}$ utes and then incubated 60 minutes at $37{ }^{\circ} \mathrm{C}$ with monoclonal antibodies. Positive cells were analyzed in 200 high-power fields for each group, and results were expressed as cell mean per microscopical field. Results were statistically analyzed.

Specific anti-OVA IgE titres were evaluated by passive cutaneous anaphylaxis PCA (26).

\section{RESULTS}

Passive cutaneous anaphylaxis (PCA) showed specific anti-OVA IgE in sensitized groups (G2 and G3) at 1/160 dilution.

Histopathology showed a patchy distribution of mucosal edema, lymphangiectasia and eosinophil infiltration in sensitized and challenged groups (G3). Eosinophils infiltrate mucosa near the surface epithelium. No changes could be detected in the control group (G1) and the sensitized, unchallenged group $(\mathrm{G} 2)$.

Data related to the immune-cell population were expressed in table I. CD4-positive cells (Fig. 1) were found in the lamina propria of both control and experimental groups. No significant differences were found between groups.

Table I. Cell populations in the rectal mucosa from normal rabbits, OVA-sensitized rabbits, and OVA-sensitizedand, locally-challenged rabbits. Positive cells per high-power field

\begin{tabular}{lccc}
\hline Markers & $\begin{array}{c}\text { Control } \\
n=200\end{array}$ & $\begin{array}{c}\text { Sensitized } \\
n=200\end{array}$ & $\begin{array}{c}\text { Sensitized and } \\
\text { challenged } n=200\end{array}$ \\
\hline CD 4 & $8.3 \pm 0.06$ & $13.4 \pm 0.08^{*}$ & $8.25 \pm 0.06$ \\
CD 5 & $7.3 \pm 0.05 * *$ & $9.4 \pm 0.05^{*}$ & $11.3 \pm 0.06$ \\
CD 25 & $13.2 \pm 0.08^{* *}$ & $15.1 \pm 0.13^{*}$ & $25.5 \pm 0.15$ \\
$\mu$ chain & $10.4 \pm 0.06^{* *}$ & $3.8 \pm 0.02^{*}$ & $6.0 \pm 0.10$ \\
RLA II (DR) & $11.6 \pm 0.05^{+}$ & $19.2 \pm 0.09$ & $19.1 \pm 0.11$ \\
\hline
\end{tabular}

* Different from control (G1) and (G3), $p<0.001$

**Different from (G3), $p<0.001$

${ }^{+}$Different from (G2) and (G3), $p<0.001$.

Anti-CD5 monoclonal antibodies marked total $\mathrm{T}$ cells and the B-cell subset (Fig. 2). In our experiment CD5+ cells were increased in the experimental group (G3). CD 25+ cells were increased in the challenged group (G3) (Fig. 3).

RLA II+ cells had a dendritic morphology and were homogeneously distributed throughout the rectal mucosa (Fig. 4).

\section{DISCUSSION}

OVA is a soluble antigen that induces specific IgE sensitization after subcutaneous injection. A challenge with 


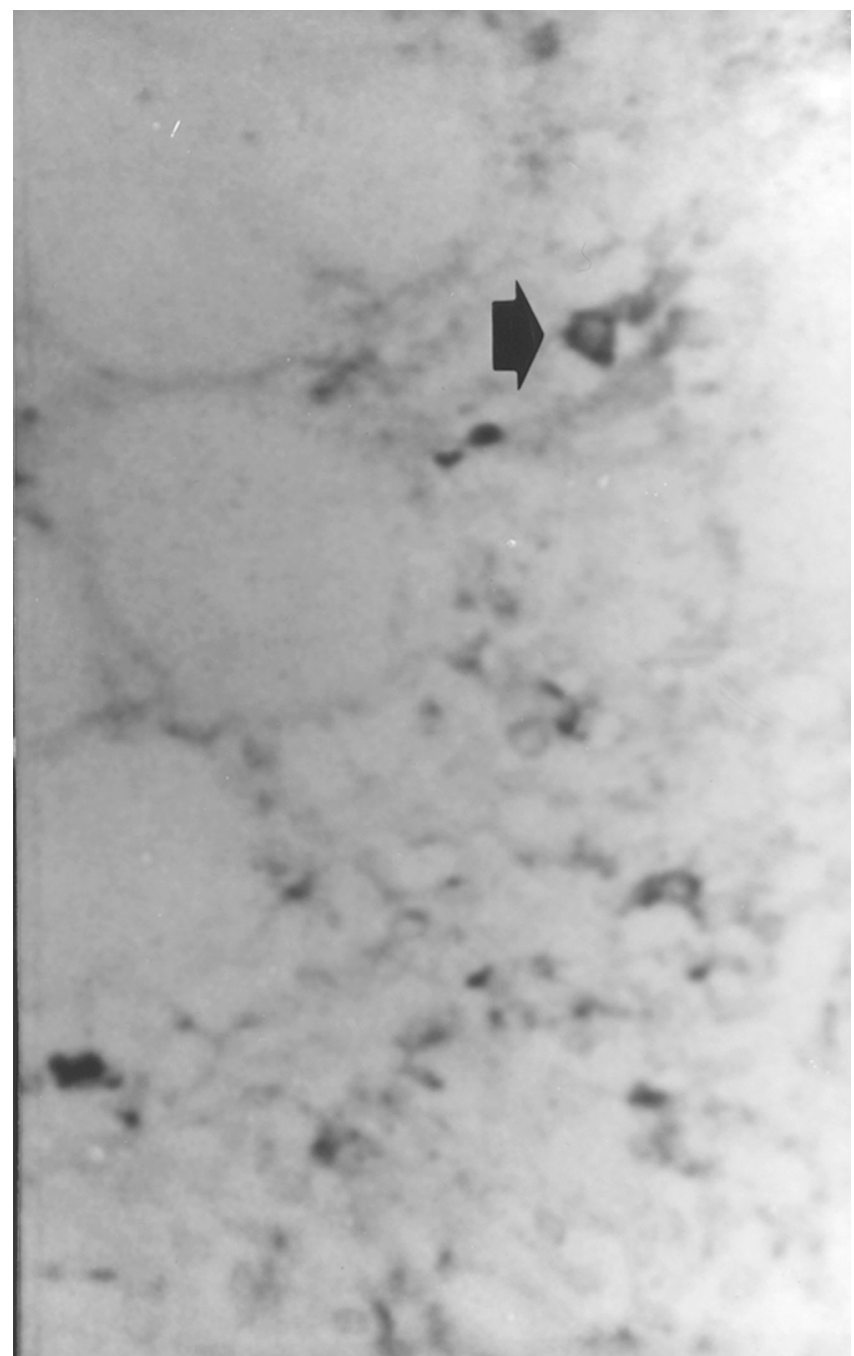

Fig. 1.- CD4+ cells in the rectal mucosa adjacent to the bottom of crypts. Sensitized, challenged rabbits. X 400. Group 3.

Células CD4 positivas en mucosa rectal adyacente al fondo de las criptas. Conejos sensibilizados y desafiados. 400 aumentos. Grupo 3.

OVA in a sensitized individual induces an allergic anaphylactic response in the digestive tract. Different food allergy models have been developed but few of them used the rectum as the studied organ. The rectum is a part of CMIS, so sensitization induced an immune response in different effector sites after challenge with the antigen.

Besides, the rectum is easy to access in terms of diagnostic procedures in order to establish cellular and histopathological patterns (27).

The maximal histopathological expression in the rectal mucosa developed 4 hours after the challenge.

Vasoactive and pro-inflammatory mediators induced mucosal edema, lymphangiectasia and eosinophil infiltration. This finding is similar to that found by other authors and our group in previous works both in the gut and other regions of the gastrointestinal tract of the rabbit $(11-28,29)$.

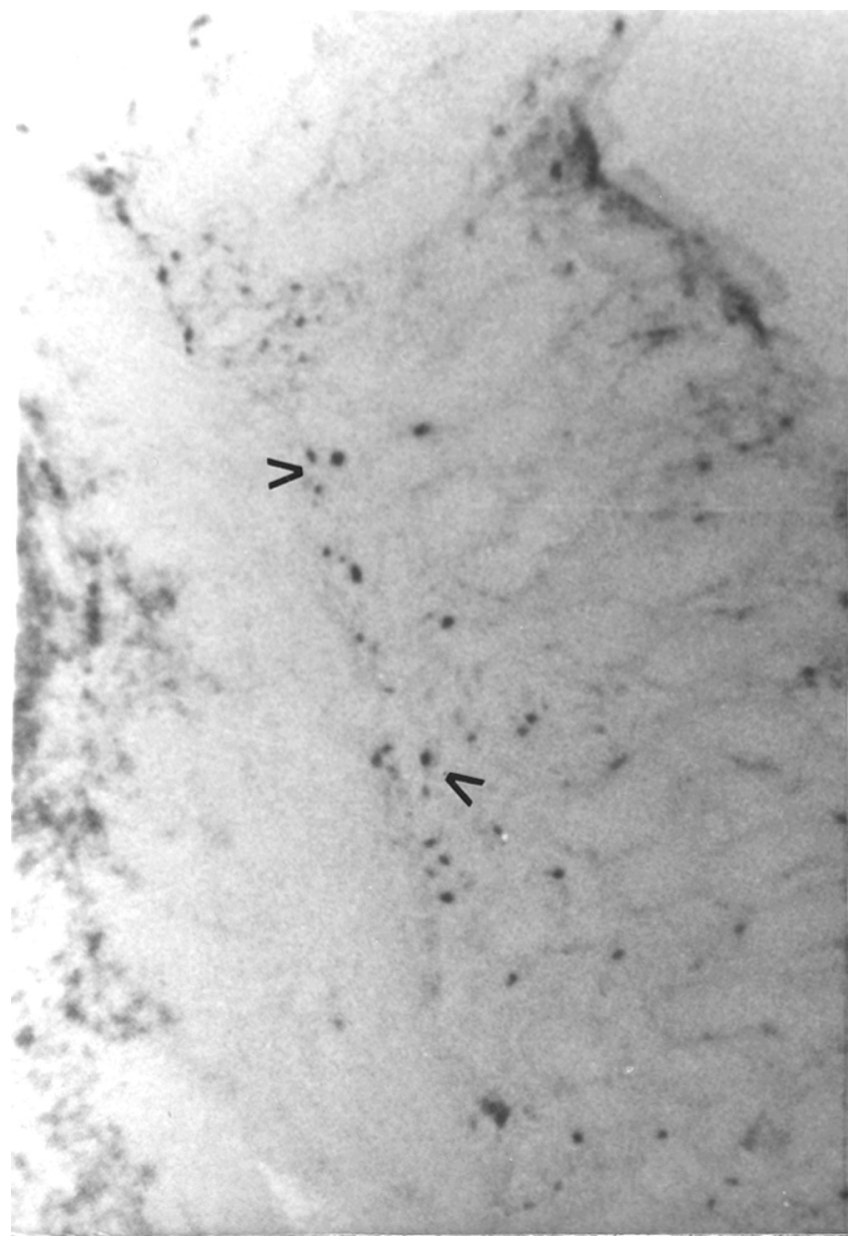

Fig. 2.- CD5+ cells in the rectal mucosa of sensitized, challenged rabbits. X 100. Group 3.

Células CD5 positivas en mucosa rectal de conejos sensibilizados y desafiados. 100 aumentos. Grupo 3.

The absence of significant statistical differences in CD4+ cells between groups is a different phenomenon to that of chronic inflammatory disorders (Crohn's disease). In this disease there is a marked increase in CD 4+ cells in the rectal mucosa. The difference between the acute and chronic pattern is probably due to a post-challenge anaphylactic reaction $(30,31)$.

It is important to point out that CD5+ cells were not observed in the rectal epithelium of sensitized and challenged rabbits. Meanwhile these cells were present in the ileal epithelium and lamina propria.

Intraepithelial lymphocytes (IEL) from the gut have cytolytic and immunoregulatory properties, and are located close to the intestinal lumen (32).

The difference between the ileum and rectum is related to the different functions of both organs in the digestive tract. The ileum is in contact with high amounts of food macromolecules, while the rectum does not get in contact with food allergens but with a high concentration of saprofitic organisms in the lumen. 


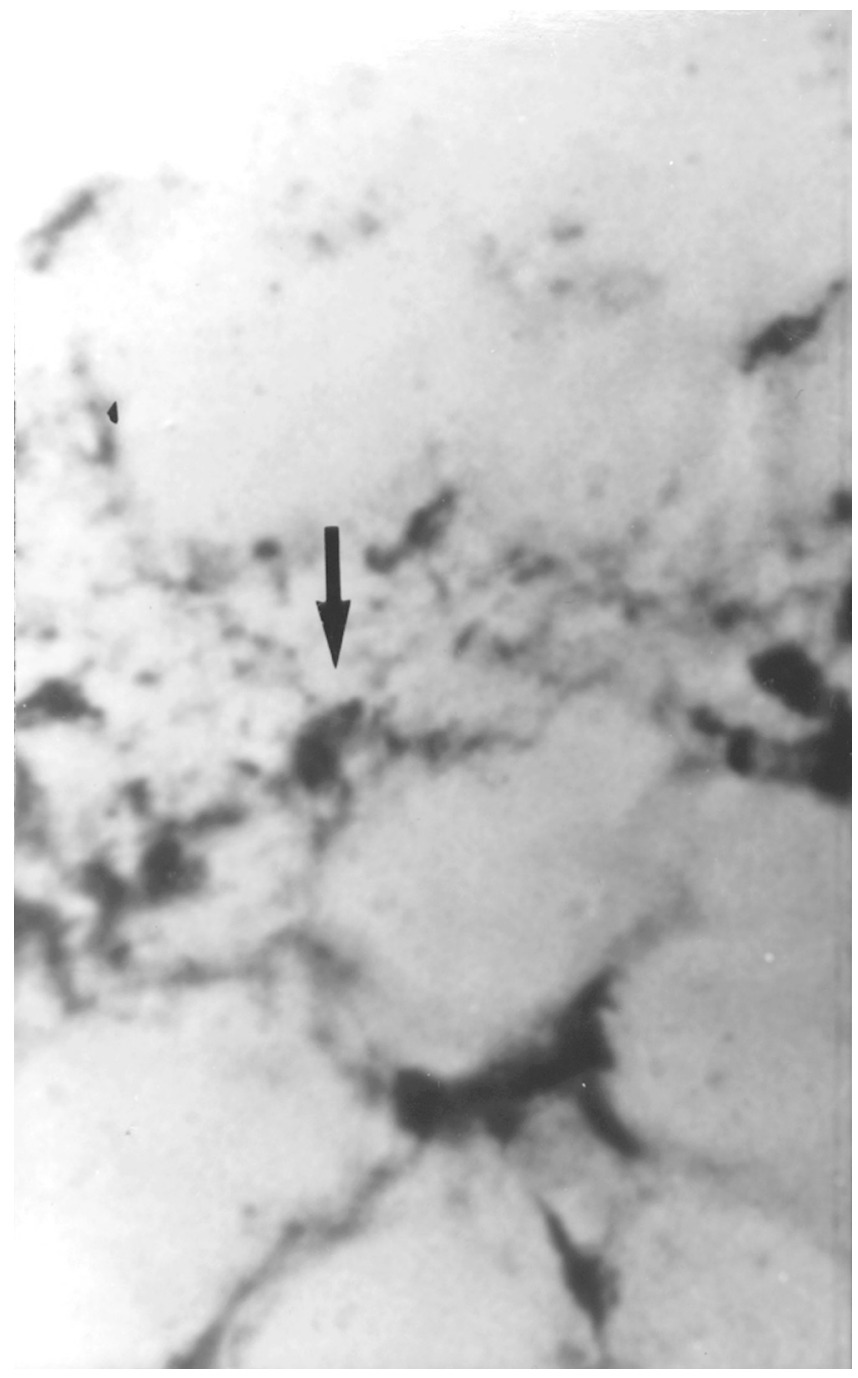

Fig. 3.- Deep area of the rectal mucosa where CD25+ cells may be seen. Sensitized, challenged rabbits. X 400. Group 3.

Zona profunda de la mucosa rectal donde se observan células CD25 positivas. Conejos sensibilizados y desafiados. 400 aumentos. Grupo III.

CD25 is an activation marker for cells participating in effector sites of allergic immune response after challenge.

Even though we did not determine the CD25 phenotype, many authors consider this a marker for macrophages due to their particular morphology. Most cells are in close proximity to the rectal epithelium. We determined CD25 expression four hours after the challenge. Barois and Choi determined that the gene expression of the IL-2 receptor starts as soon as 4 to 6 hours after a challenge $(30,31)$.

The $\mu$ chain reflected heavy chains on immature Bcells. These cells were decreased in the rectal mucosa of both experimental groups (G2 and G3). This decrease may be due to a lesser expression of $\mu$ chains in B cells because of isotype switching or because of a real decrease in cell numbers due to cell migration.

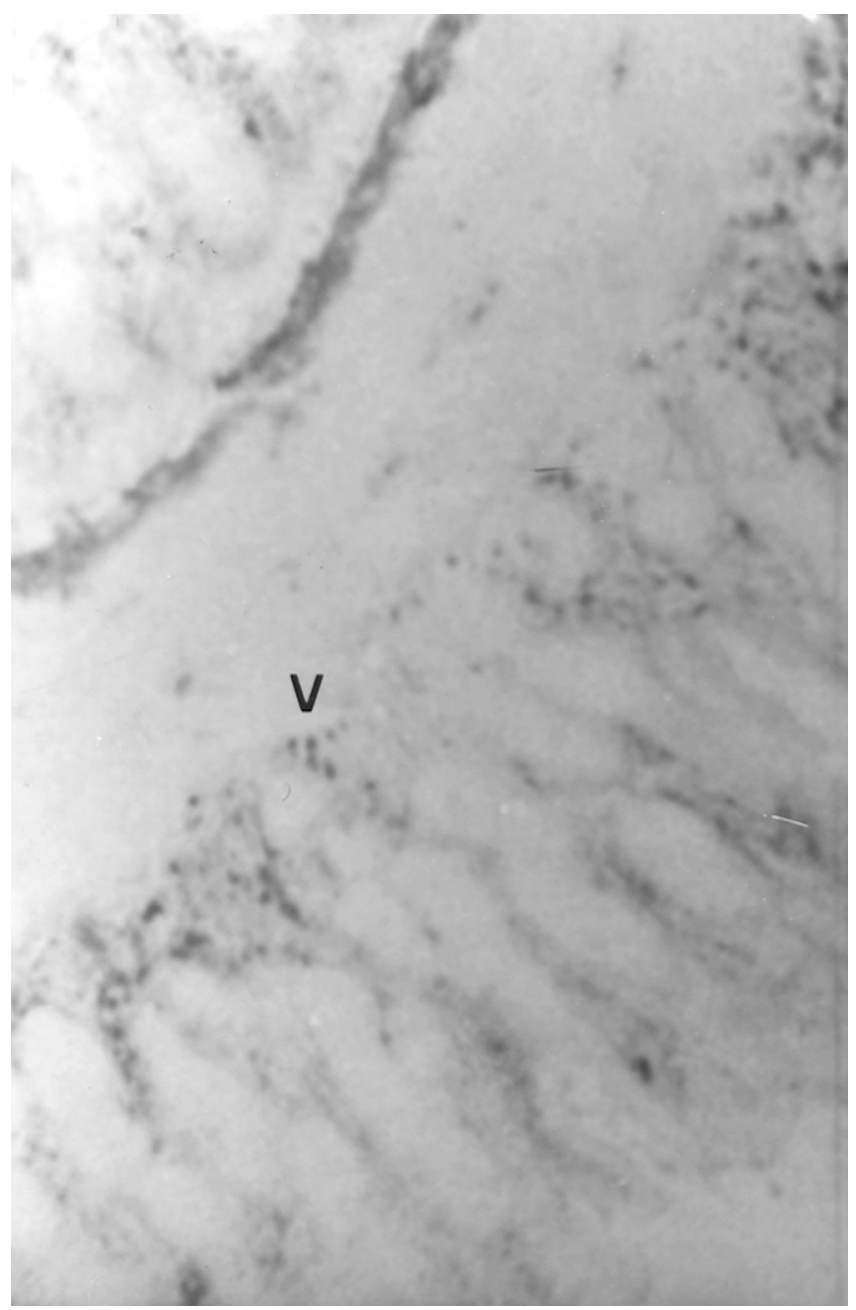

Fig. 4.- RLA II+ cells scattered throughout the rectal mucosa of sensitized rabbits. X 100. Group 3.

Células RLA II positivas dispersas en mucosa rectal de conejos sensibilizados. 100 aumentos. Grupo III.

It is important to point out that we as well as other groups have detected dendritic RLA II+ cells in close proximity to the epithelium. This localization of cells could be related to the antigen-presentation property of dendritic cells. Double stain studies are necessary to establish phenotypes. Other RLA II characteristic is that these cells are in groups beneath the epithelium.

A result, let us conclude that OVA sensitization and challenge induced quantitative modifications in studied cells. Such quantitative data may be considered an immunopathological pattern for acute anaphylactic reactions in the rectal mucosa of systemically sensitized animals.

\section{REFERENCES}

1. Brandtzaeg PE. Current understanding of gastrointestinal immunoregulation and its relation to food allergy. Ann N Y Acad Sci 2002; 964 : $13-45$. 
2. Taylor SL, Hefle SL. Food science perspective on food allergy. Allergy 1998; 53: 5-7.

3. Holt PG. Mucosal immunity in relation to the development of oral tolerance/sensitization. Allergy 1998; 53: 16-9.

4. Mayer L. Mucosal immunity and gastrointestinal antigen processing. J Pediatr Gastroenterol Nutr 2000; 30: 4-11

5. Brandtzaeg P. The human intestinal immune system: Basic cellular and humoral mechanisms. Baillieres Clin Rheumatol 1996; 10: 1-24.

6. Strober W, James SP. The immunologic basis of inflammatory bowel disease. J Clin Immunol 1986; 6 : 415-32.

7. van Ree R, Akkerdaas J, van Leeuwen A, Fernández Rivas M, Asero R, Knul-Bretlova A et al. New perspectives for the diagnosis of food allergy. Allergy Clin Immunol Int 1998; 12: 7-12.

8. Sampson HA. Food allergy. JAMA 1999; 278: 188894.

9. Placenti G, Bertolini A, Spezia E, Piscione T, Boner AL. Ability of new infants formula prepared from partially hydrolysed whey to induce anaphylactic sensitization: evaluation in guinea pig model. Allergy 1994; 49: 361-4.

10. Miller K, Laugee J, Meredith C. The monitoring of effects of food components on immunoreactivity in experimental animals. Allergy 1998; 53: 35-7.

11. Vinuesa M, Tanaka Y, Hakugawa J, Jae Bae S, Katayama I. In-situ expression of interleukin $-4,5$ and 6 in Peyer's Patch from Ovalbumin (OVA)-sensitized $\mathrm{BALB} / \mathrm{c}$ mice after oral challenge. Int Allergol 1997; 46: 243-7.

12. Sampson HA. Food allergy. Part I: Immunopathogenesis and clinical disorders. J Allergy Clin Immunol 1999; 5: 717-29.

13. Sabbah A, Drouet M, Luret MG, Giffard G, Minkhar M. Cross reactivity between cow's milk and goat's milk. Allerg Immunol 1997; 29: 203-14.

14. Ahmed T, Fuchs G. Gastrointestinal Allergy to food: A review. J Diarrheal Dis Res 1997; 15: 211-23.

15. Ramírez Cruz NE, Castrejón Vázquez MI, Espinoza Goldman MB, Martínez-Cairo Cueto S. Prevalence of latex-fruit syndrome in health workers with latex allergy. Rev Alerg Mex 2002; 49: 46-51.

16. Moller M, Kayma M, Vieluf D, Paschke A, Steinhart $H$. Determination and characterization of crossreacting allergens in latex, avocado, banana, and kiwi fruit. Allergy 1998; 53: 289-96.

17. Mage RG. Immunology of lagomorphs. En: Pastoret P, Griebel P, Bazin H, Govaerts A, eds. Handbook of Vertebrate Immunology. San Diego: Academic Press, 1998. p. 223-60.

18. Fekete S, Bonori J. The effect of the fiber and protein level of the ration upon the cecotrophy of rabbit. J Appl Rabbit Res 1985; 8: 68-71.

19. Hollyster AG. Effects of water administrated probiotics and acidifiers on growth feed conversion and enteritis mortality of weaning rabbit. J Appl Rabbit Res 1989; 12: 143-7.

20. Fekete $S$. Recent finding and future perspectives of rabbit's digestive physiology. Cuni Sciences 1987; 4: $1-9$.

21. Bassan N, Vinuesa M, Roma S, Pérez F. Biological model for detection of food antigens. Arch Latinoam Nutr 2002; 52: 249-56.

22. Cellier C, Cervoni JP, Leborgne M, Marteau P, Landi $\mathrm{B}$, Cerf-Bensussan N, et al. Gluten-free diet induces regression of $\mathrm{T}$-cell activation in the rectal mucosa of patients with celiac disease. Am J Gastroenterol 1998; 93: $1527-30$.

23. Ensari A, Marsh M, Loft D, Morgan S, Moriarty K. Morphometric analysis of intestinal mucosa. V Quantitative histologic and immuno-cytochemical studies of rectal mucosae in gluten-sensitivity. Gut 1993; 34: 1225-9.

24. Troncone R, Mazzarella G, Leone N, Mayer M, De Vincenzi M, Greco L, et al. Gliadin activates mucosal cell mediated immunity in cultured rectal mucosa from coeliac patients and a subset of their siblings. Gut 1998; 43: 484-9.

25. Kotani M. Generation and characterization of monoclonal antibodies against rabbit CD4, CD5 and CD11a antigens. J Imm Meths 1993; 157: 241-52.

26. Bassan N, Vinuesa M, Pérez F, Roma S, Bernardi S, Lagrutta M. Mastocitos Azul Alciano positivos en la mucosa del ciego de conejos normales y esplenectomizados, sensibilizados y desafiados con ovoalbúmina. Analecta Veterinaria 1998; 18: 15-20.

27. Honma K, Kohno Y, Hirano K, Shimojo N, Suzuki H, Hoshioka A, et al. Diagnosis of food allergy based on rectal mucosa cytology. Arerugi 1992; 41: 749-56.

28. Perdue M, Chung M, Gall G. Effect of intestinal anaphylaxis on gut function in the rat. Gastroenterol 1984; 86: 391-7.

29. Bassan N, Vinuesa M, Pérez F, Roma S, Bernardi S. Células enteroendocrinas intraepiteliales en ciego y apéndice de conejos sensibilizados con ovoalbúmina. Acta Gastroenterol Latinoam 1999; 29: 313-7.

30. Barois N, De Saint-Vis B, Lebecque S, Geuze HJ, Kleijmeer MJ. MHC Class II Compartments in human dendritic cells undergo profound structural changes upon activation. Traffic 2002; 3: 894-905.

31. Choy M, Walker-Smith J, Williams C, MacDonald T. Differential expression of CD25 (interleukin-2 receptor) on lamina propria $\mathrm{T}$ cells and macrophages in the intestinal lesions in Crohn's disease and ulcerative colitis. Gut 1990; 31: 1365-70.

32. Vinuesa M, Roma S, Bassan N, Pérez F. Characterization of intraepithelial $\mathrm{T}$ cell population in terminal ileum from ovalbumin (OVA) sensitized New Zealand rabbit. J All Clin Immunol 1997; 4: 746.

33. Kelsall B, Strober W. Distinct populations of dendritic cells are presents in the subepithelial dome and $\mathrm{T}$ cell regions of the murine Peyer's patch. J Exp Med 1996; 183: 237-47. 